\title{
The mediating role of social workers in the implementation of regional policies targeting energy poverty
}

\author{
Sabina Scarpellini \\ Department of Accounting and Finance - CIRCE - University of Zaragoza - \\ E-mail: $\underline{\text { sabina@unizar.es }}$ \\ M. Alexia Sanz Hernández \\ Department of Psychology and Sociology - University of Zaragoza \\ E-mail: alexsanz@unizar.es \\ Eva Llera-Sastresa \\ Department of Mechanical Engineering - CIRCE - University of Zaragoza \\ E-mail: ellera@unizar.es \\ Juan A. Aranda \\ CIRCE Foundation - Research Centre for Energy Resources and Consumptions - University of Zaragoza \\ E-mail: juan.aranda@unizar.es \\ María Esther López Rodríguez \\ Department of Psychology and Sociology - University of Zaragoza \\ E-mail: estherlo@unizar.es
}

KEY WORDS: Household energy poverty, energy training, social workers, energy policy.

\begin{abstract}
This paper aims to provide a socio-political reflection of the role played by social workers in regional policies and of the real needs of households affected by energy poverty. The paper also examines the impact of technical-specialised training on the ability of social workers to prevent and mitigate conditions of household energy poverty in Europe.

The adoption of a research-action-participation methodological framework and a training research approach has permitted the opinions of social workers to be collected through surveys, and their central role in implementing regional policies to be highlighted. The conclusions obtained have made possible the construction of a self-diagnosis and data-collection tool which increases the ability of social workers to mediate and implement urgent mitigation measures for energy impoverished households.

Finally, regional policies which aim to mitigate household energy poverty are examined from the professional perspective of social workers.
\end{abstract}




\section{1.- Introduction}

Over the last few years, the European Union (EU) has adopted different initiatives to evaluate energy vulnerability at local, regional and national level, in an attempt to protect citizens from energy poverty (Bouzarovski, Petrova, and Sarlamanov 2012) and prevent social exclusion by guaranteeing access to energy for reasonable and stable prices (European Economic and Social Committee 2013). These issues were recognized in the Third Energy Package in 2009 (Eikeland 2011), in which EU member states are directed to adopt the appropriate measures to protect consumers, and partially addressed in the so-called "winter package” at the end of 2016 (European Commission 2016).

As pointed out by Bergasse et al. (2013), when households have to spend an excessive proportion of their income on energy, they are considered to be in a position of energy vulnerability, which may lead to a deterioration in living standards and have a negative effect on overall socioeconomic development. National public policies among EU members are, however, fragmented, both in terms of the definition of energy poverty and of the assessment and definition of prevention and mitigation measures.

This fragmentation is also linked to the different incidence of household energy poverty in different European countries. Energy poverty is a much more serious problem in Southern and Eastern Europe (Healy and Clinch 2002; Sergio Tirado Herrero and Bouzarovski 2015), especially in the Mediterranean region, where it is estimated that $16.6 \%$ of the households do not generally live in conditions of thermal comfort. The European average is approximately 4\% lower (Bouzarovski 2011).

European policies on the matter are patchy, owing to the fact that specific measures have been implemented by individual member states; this has limited the scope of EUwide policies. Furthermore, a comprehensive understanding of energy poverty in each country depends on the availability of primary data, and some authors pointed out that a holistic perspective on everyday energy practices in low-income households that are undergoing energy poverty is needed at local and national level (Howden-Chapman et al. 2012; Brunner, Spitzer, and Christanell 2012).

The first obstacle to analysing energy poverty is related to definition: there is no unanimously accepted EU-wide academic definition of household energy vulnerability or energy poverty.

The earliest European definitions, which follow Boardman's pioneering publication (1991), established that a household suffered from energy poverty if it had to use over $10 \%$ of its income to meet basic energy expenses, which were those conducive to maintaining a temperature at home that varied between 18 and $21^{\circ} \mathrm{C}$ (BERR 2001; Rudge 2001). This definition was later challenged and revised by different authors, who distinguished between electricity consumption and the use of combustion-based heating systems (Morrison and Shortt 2008; Rudge 2012; J. Hills 2012) suggested that a household is in a situation of energy poverty when the costs of attaining sufficient thermal comfort are above average, provided that household income is under the poverty threshold $(60 \%$ of the median income after deducing non-energy related housing expenses). 
The International Energy Agency (IEA - International Energy Agency 2011) established that a household is in a situation of energy poverty when the energy-related costs bear too heavily on the total income. This definition is very similar to that put forward by Tirado-Herrero et al. (2012) in one of the earliest Spanish publications on this subject. On the other hand, the report 'Energy Poverty in the EU' (Thomson and Snell 2013) incorporated the concepts of the 'cold home' and household 'energy debt' into existing definitions.

Based on the relative definition of energy poverty provided by Grevisse \& Brynart (2011), it seems appropriate for this study to adopt a definition according to which a household is in a position of energy poverty when it cannot afford the services conducive to satisfying recognised household needs. The definition, therefore, introduces the need for a mediating agent which can 'classify' households in terms of energy vulnerability on behalf of the relevant public social services (Scarpellini et al. 2015).

Given the differences in definition, we may question what model is accepted by public agencies in a European context, what role is being played by social workers involved in detecting, certifying and mitigating energy poverty in households, and finally what methods are being used for the detection and assessment of energy poverty in households The results presented in this article are based on these three research questions, and are focused in the context of a Spanish region characterised by the presence of active cooperative movements for energy poverty prevention (Scarpellini, Perales, and Poc 2014).

In general, energy poverty in Spain is being addressed through the implementation of emergency measures which aim to avoid households being cut off, and through the provision of necessary financial resources to those households who cannot afford to pay their energy bills. Data indicate that the problem is increasing in Spain (S. Tirado Herrero. et al. 2014; S. Tirado Herrero et al. 2016) because the effects of the economic crisis have been particularly severe among the most vulnerable social groups (OECD 2016).

Based on this premise, and after the next section, which will provide the background for the research presented in this paper, our aim is to analyse a regional energy povertypolicy model from the perspective of the social agents responsible for certifying energy impoverishment. These agents are key to ensuring that the model is efficacious, flexible and capable of responding to urgent energy-related needs. The empirical results obtained and the training scheme which was designed for the relevant social workers led to the development of a self-diagnosis tool, which was used in the certification of energy impoverishment; this will be presented along with our discussion of the regional policies currently in place. Finally, the main conclusions will be summarised.

\section{2.- BACGROUND}

Energy poverty should not be interpreted in isolation from the overall processes of impoverishment and growing inequality that can be observed presently in countries such as Spain (Moretón 2015; Bellver 2015; García Escalera 2015). In fact, during the last decades, the poverty characterised by the progressive, and chronic, impoverishment of the middle layers of society has increased specially in Latin America (Kliksberg 1995; Barbeito and Lo Vuolo 1992), but also affects European middle classes (Laparra and 
Casado 2013). For this reason, this paper is focused on the role played by social workers in dealing with poverty (Laparra and Casado 2013), and the problem is addressed using an interdisciplinary approach which incorporates a socio-political perspective.

An examination of the relevant literature in this field reveals that energy poverty is often identified on the basis of the proportion of overall income used to meet energy costs (Brenda Boardman 2012), or other measurements based on comfort criteria (Roberts 2008; G. Walker and Day 2012), and the identification of households that are suffering energy poverty (Dubois 2012; Li et al. 2014) is considered relevant to the design of appropriate mitigation measures (Chaudhuri and Ravallion 1994).

The macro-analysis of energy poverty on a European-wide scale (Liddell et al. 2012; Moore 2012; Rosenow, Platt, and Flanagan 2013; Heindl 2015) and regional scale (Fahmy, Gordon, and Patsios 2011; R. Walker et al. 2013), has received a fair amount of attention in this decade. In recent years, more attention has been paid to the measurement of the phenomenon (Morrison and Shortt 2008; Pachauri and Spreng 2011; Waddams Price, Brazier, and Wang 2012; Rudge 2012; Heindl 2015), as well as to possible solutions (Brenda Boardman 2004; Darby 2012; European Economic and Social Committee 2012; Guertler 2012; Saunders, Gross, and Wade 2012; Sergio Tirado Herrero and Ürge-Vorsatz 2012), subsidy policies (Dartanto 2013) and the efficiency of public funds earmarked to help households living under conditions of social exclusion (Copiello 2016).

In the recent years, the household-focused studies are increasing among the academics (Roberts 2008; Devalière 2010; Mathew Santamouris, Paravantis, Founda, Kolokotsa, Michalakakou, and Papadopoulos 2013; Mathew Santamouris, Paravantis, Founda, Kolokotsa, Michalakakou, Papadopoulos, et al. 2013; S. Tirado Herrero. et al. 2014; Scarpellini et al. 2015). In this field, some authors have identified the lack of uniformity among European and national statistical data as a limitation, as well as a shortage of data and a lack of surveys and specific methodology for measuring the phenomenon (Heindl 2015). According to Santamouris et al. (2007), energy consumption is directly related to the socioeconomic profile of the household and the habits of its members. Energy tariffs has been pointed out as well in determining energy costs in energy poverty situations (Yu et al. 2011; Majcen, Itard, and Visscher 2015).

When we look closely at the analysis of preventive or palliative proposals, Grevisse \& Brynart (2011) provide a synthesis of the measures undertaken in the European Union, differentiating between the activities aimed at consumer protection and those designed to avoid disconnection of energy supply. The inadequate building features of dwellings has been analysed as a relevant factor in increasing the relative degree of energy poverty in households (Bahaj and James 2007; Sdei et al. 2015; Terés-Zubiaga et al. 2013; Jenkins 2010) Additionally, social housing has been a subject of some authors because it may be particularly related to energy poverty (John Hills 2012; Li et al. 2014).

Nevertheless, despite growing interest of academics, there are still many aspects to be explored about energy poverty in households as the dissemination of information, which has recently been analysed by Bartiaux et al. (2016), or the role of social workers dealing with energy-impoverished households in the EU, that is the main subject of this paper. It means to discern what role social workers - regardless of whether they work for a public social service or a private NGO - play in the mitigation of energy poverty 
and the management of the specific funds available in some regions for the palliation of this problem.

In this context, the analysis presented in this paper is based on a regional case study and also aims to propose a specialised energy training initiative specifically designed to advance the results of the mediating role played by social workers, with the ultimate purpose of improving institutional responses to the needs of impoverished households.

\section{3.- CASE STUDY AND METHODOLOGY}

The case study is the region of Aragón, in northern Spain. Aragon has been among the first regions to entrust social workers with the task of certifying cases of energy poverty (Scarpellini et al. 2015).

In 2015, the region had a population of 1,317,847, spread across 731 municipalities (over half the region's inhabitants live in the capital). Social exclusion and poverty rates in the region (17.7\%) are well below the national average (28.6\%). Territorially and demographically, the region presents the following figures (CESA 2016): population loss (-1.6\% in 2015), low population density $\left(25 \mathrm{p} / \mathrm{km}^{2}\right)$, an increasingly aged population (and, in consequence, a high dependence rate; $56 \%$ of the population is economically inactive), and a negative migratory balance (75\% of the municipalities have fewer inhabitants than in 2005).

The region has adopted a policy of territorialising social policies, and thus promoted proximity to vulnerable subjects, which has been fostered by the EU in recent decades (Hamzaoui 2005). In this way, council-based policies (regulated by the Local Administrations $\mathrm{Act}^{1}$ ) have been complemented by district-wide social services ${ }^{2}$ and also by private NGOs which, during the worst episodes of the economic crisis have gone a long way to mitigating the shortcomings of the public system (see Figure 1).

The regional Social Services $\mathrm{Act}^{3}$ establishes the catalogue of public social benefits and divides these into services, economic subsidies and technological assistance. This Act, was further developed by a decree ${ }^{4}$ that regulated urgent subsidies which are, in essence, one-off monetary handouts which aim to ensure families do not lose their primary residence, adequate living conditions are maintained and, finally, electricity and other energy expenses are covered.

As previously noted, in the Region monitoring situations of energy poverty is the responsibility of social workers employed by the local administration. For this reason, almost all district and local councils have enacted specific regulations with which to ensure that the energy needs of vulnerable homes are met. In 2014, 2015 and 2016, several bilateral agreements were signed with the main utility companies in the region, in order to facilitate the management of outstanding energy bills and thus the protection of vulnerable households.

\footnotetext{
${ }^{1}$ Ley 7/1985 Reguladora de las Bases del Régimen Local.

${ }^{2}$ After the central government transferred responsibility for social services to the regional governments in 1996, social policies have become institutionalised and professionalised within the framework of this district-based system of social policies (Decreto 4 /2005, de 11 de enero, del Gobierno de Aragón).

${ }^{3}$ Ley 5/2009, de 30 de junio, de Servicios Sociales en Aragón

${ }^{4}$ Decreto 143/2011, de 14 de junio, del Gobierno de Aragón.
} 
These agreements are legally binding, according to the Mitigation of Energy Poverty Act ${ }^{5}$ which sets out the need to certify energy vulnerability in economic terms ${ }^{6}$ and coordinate agents and those affected by energy poverty, in order to improve detection, measurement, regulation and mitigation, after the model adopted in other areas (for instance, mitigation of child poverty).

Thus, whenever social workers detect that household is in danger of having the power supply cut off, they carry out an assessment of the specific case in order to establish whether the person/family is/are in danger of social exclusion, and whether they are entitled to receive an economic subsidy which could be used to pay the energy bill. The utility company are informed of the situation, and the possibility of continuing or reconnecting the energy supply, following the relevant agreement, is contemplated.

In any case, the mitigation measures that are eventually implemented in order to tackle energy poverty revolve around the social worker, as illustrated in Figure 1.

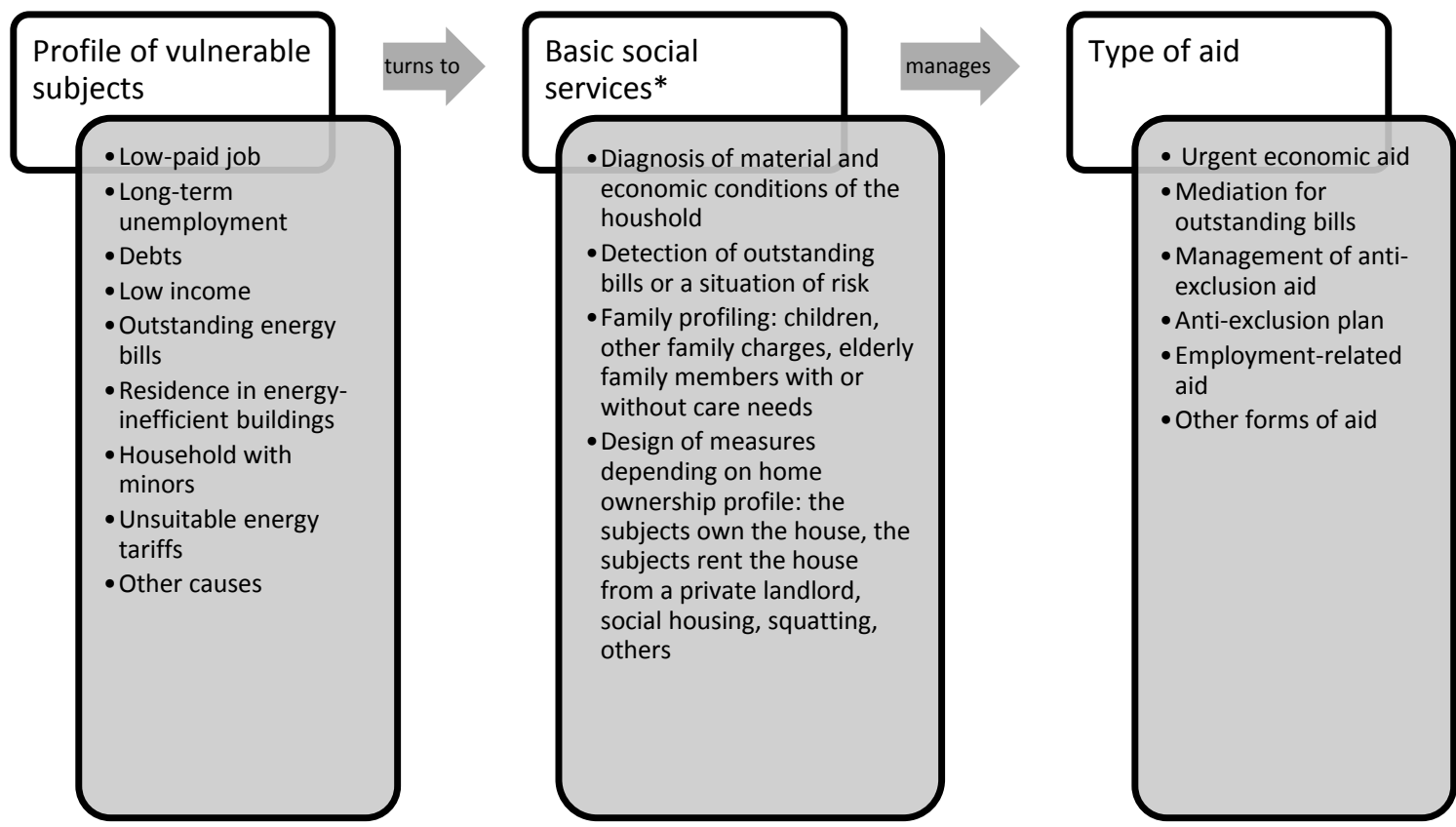

Figure 1.-Basic outline of the process involved in granting emergency economic aid $^{7}$ in situations of certified energy poverty

The following figure illustrates the evolution of subsidies provided by public agencies and social NGOs; $85 \%$ of the aid was granted to households in the regional capital (Zaragoza), and 89\% in urban areas.

\footnotetext{
${ }^{5}$ Ley 9/2016 of the 3rd of November: Mitigation of Energy Poverty Act of the Region of Aragón (Ley de Reducción de Pobreza Energética de Aragón).

${ }^{6}$ The threshold is established with reference to the so called "IPREM", an income indicator which is currently set at a gross $€ 532 /$ month. The vulnerability threshold is set at 2xIPREM/month.

${ }^{7}$ In some cases the case is first handled by a private NGO, which generally provides a one-off emergency handout and puts the case in the hands of the basic social services.
} 


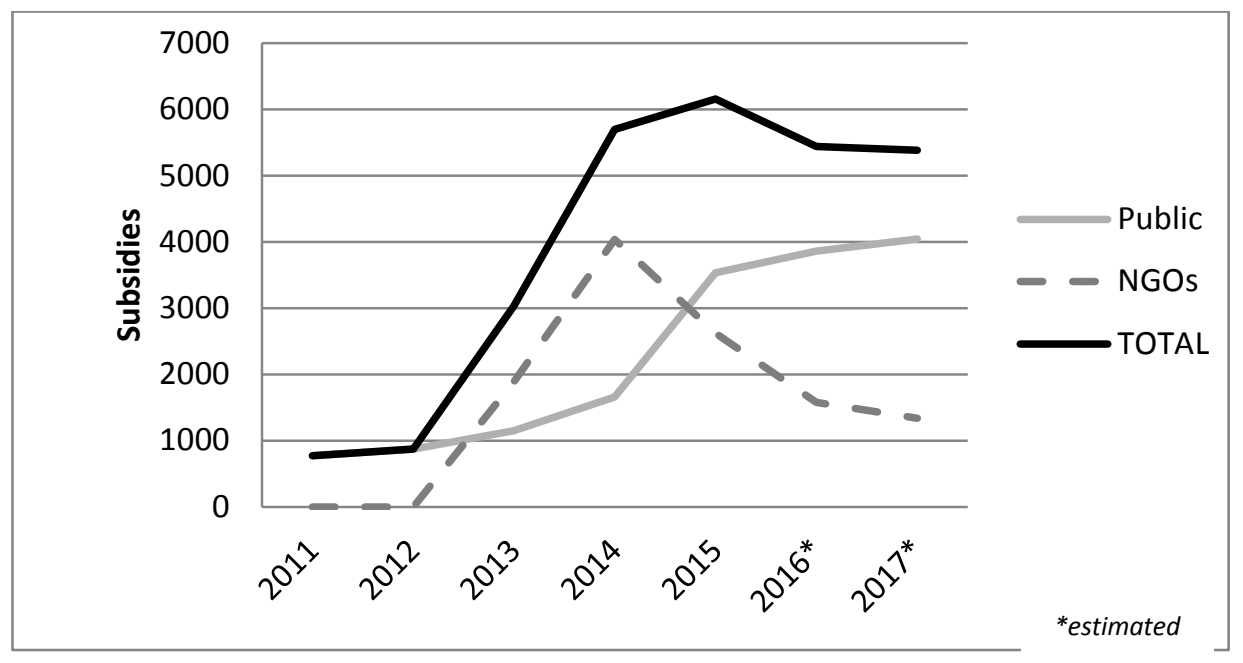

Figure 2.- Evolution of the aid granted in situations of certified energy poverty.

Another interesting aspect is the involvement of social NGOs in tackling energy poverty, as illustrated in Table 1.

\begin{tabular}{|c|c|c|c|c|c|c|c|c|c|c|c|c|c|c|}
\hline & \multicolumn{2}{|l|}{2011} & \multicolumn{2}{|l|}{2012} & \multicolumn{2}{|l|}{2013} & \multicolumn{2}{|l|}{2014} & \multicolumn{2}{|l|}{2015} & \multicolumn{2}{|c|}{2016 (forecasted) } & \multicolumn{2}{|c|}{2017 (estimated) } \\
\hline & $\begin{array}{c}\text { Subsidies } \\
\text { (Euros) }\end{array}$ & $\%$ & $\begin{array}{c}\text { Subsidies } \\
\text { (Euros) }\end{array}$ & $\%$ & $\begin{array}{c}\text { Subsidies } \\
\text { (Euros) }\end{array}$ & $\%$ & $\begin{array}{c}\text { Subsidies } \\
\text { (Euros) }\end{array}$ & $\%$ & $\begin{array}{c}\text { Subsidies } \\
\text { (Euros) }\end{array}$ & $\%$ & $\begin{array}{c}\text { Subsidies } \\
\text { (Euros) }\end{array}$ & $\%$ & $\begin{array}{c}\text { Subsidies } \\
\text { (Euros) }\end{array}$ & $\%$ \\
\hline \begin{tabular}{|l|} 
Public Social \\
Services
\end{tabular} & $131,493.58$ & $100 \%$ & $144,558.98$ & $100 \%$ & $191,928.16$ & $33.7 \%$ & $368,456.14$ & $31.3 \%$ & $635,760.00$ & $54.8 \%$ & $695,421.00$ & $68.8 \%$ & $726,081.3$ & $79.0 \%$ \\
\hline NGOs & n.a. & & n.a. & & $377,191.34$ & $66.3 \%$ & $807,445.31$ & $68.7 \%$ & $524,839,45$ & $45.2 \%$ & $314,903.67$ & $31.2 \%$ & $192,721.04$ & $21.0 \%$ \\
\hline TOTAL & $131,493.58$ & & $144,558.98$ & & $569.119,50$ & & $1,175,901.45$ & & $1,160,599.45$ & & $1,010,324.67$ & & $918,802.34$ & \\
\hline Variation & & & $9.94 \%$ & & $293.69 \%$ & & $106.62 \%$ & & $-1.3 \%$ & & $-12.95 \%$ & & $-9.06 \%$ & \\
\hline
\end{tabular}

Table 1.- Private-public type of energy poverty-related aids for households in situations of certified energy poverty.

As the table clearly illustrates, after the signing of the agreements with utility companies in late 2014 and 2015, and the changes to local rules that regulated the management of these subsidies, the proportion of aids provided by NGOs dropped, while that provided by public agencies increased - a change in comparison to the trends detected in 2013 and 2014. Previously, aid provided by private NGOs was twice that provided by public bodies, whereas now the situation is the opposite.

Although they are limited by political and administrative caveats, social workers are assessing an increasing number of households and their lack of specific training could limit their ability to assess the problem adequately and, importantly, to suggest preventive, as opposed to simply palliative, measures, as well as to detect potential fraud.

With these premises, a specific training program was designed and carried out at regional level, to explore in deep the issue of energy poverty and to develop new measures with which to tackle it (reflection/action) in collaboration with social workers.

\subsection{Specialised training}


The training program of 20 3-hours sessions was made possible by the cooperation of private and public entities ${ }^{8}$. There were 169 attendees, $77.5 \%$ of whom were social workers for local administrations which are responsible for providing urgent aid to vulnerable households. Workers affiliated with social NGOs constituted $21.9 \%$ of the attendees.

In general, the training program was positively received (the average score was 7.98/10) and the involvement of the social workers was highly satisfactory, as illustrated by the figure 3.

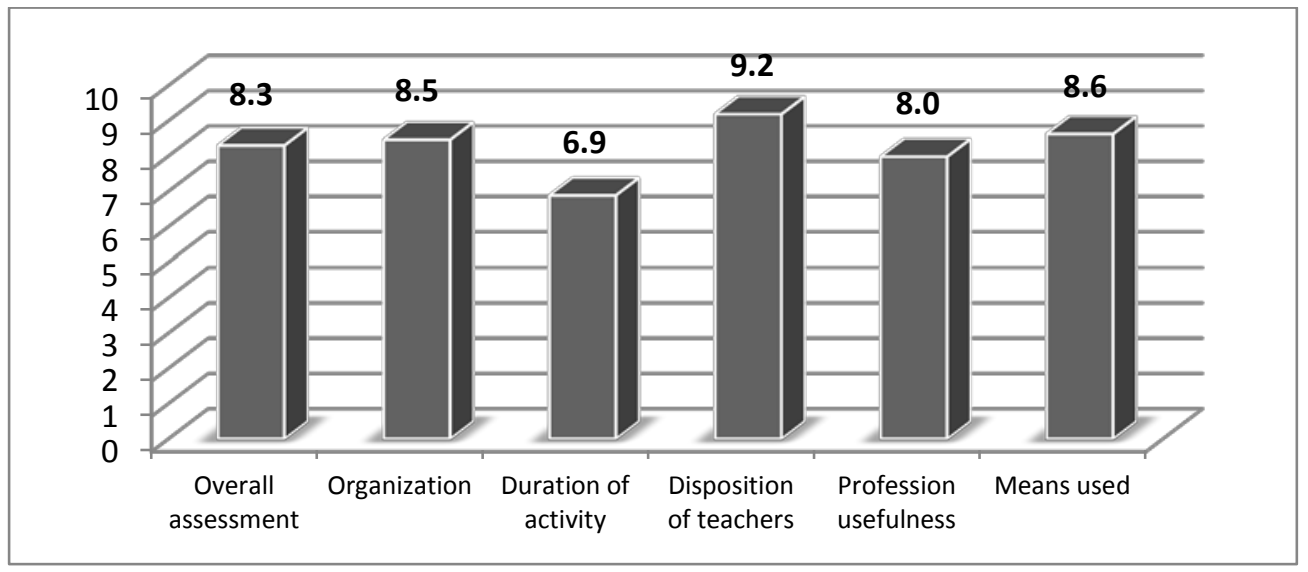

Figure 3.- Participants' assessment of different aspects of the energy training programme

Importantly, the attendees largely declared that their professional activity would benefit from the programme (7.98/10). This generated some debate and difference of opinion between those attendees who are in direct contact with energy-impoverished households and in charge of managing the emergency mitigation measures - those who regard the training programme as highly beneficial for their daily work - and those attendees not in direct contact with the households (educators, NGO workers, etc.), who generally consider the content of the programme as not applicable to real settings. Despite this difference of opinion, the need for this sort of training initiative is clear, as demonstrated by the fact that all available places were taken and that many attendees requested information on future programmes. The aspects that the attendees appreciated most were the sections on electric plans/tariffs and billing and information on the source of the energy costs incurred by the households with which they were working.

During the sessions, participation instruments were implemented in order that social workers were able to offer their points of view on the social challenge posed by energy poverty. Similarly, a specific survey was elaborated, in order to compile the data necessary for an in-depth analysis of the perspectives of professionals about energy poverty in the region.

The first part of the survey (Table 2) aimed to characterise, identify and classify the professionals completing the questionnaire, while the second section included eleven questions which touched on key topics concerning household energy vulnerability and poverty (answers were structured according to a Likert scale, with scores ranging from 0

\footnotetext{
${ }^{8}$ In spring 2016, the Regional Government presented a training programme that specifically addressed the issue of energy poverty. The programme was directed at those social workers who dealt with vulnerable households. The initiative was funded by Fundación Endesa (affiliated with the main electricity company in the region) and implemented by a research centre specialising in energy matters (CIRCE), in cooperation with the regional institute of social services and the University of Zaragoza. For more information, visit: www.fcirce.es/vulnerabilidadenergetica (accessed November 2016).
} 
to 10: 0 being totally disagree with the statement and 10 totally agree). Table 3 summarises the questions and the main results. At this stage, the analysis is purely statistical-descriptive.

During the training course, the attendees were provided with a self-diagnosis tool with which, using 208 variables, they identified four aspects which determine energy poverty: architectural characteristics, household facilities, energy costs and habits of household members. This information is summarised in the table 2.

\begin{tabular}{|c|c|}
\hline ARCHITECTURAL CHARACTERISTICS & HOUSEHOLD EQUIPMENT \\
\hline $\begin{array}{l}\text { Potential problems in the architectural characteristics of } \\
\text { the primary residence. Isolation and ventilation. Energy } \\
\text { efficiency issues. } \\
\text { - Possible low cost measures on envelope improvement. } \\
\text { - Possible low cost measures on passive gains } \\
\text { - Possible measures in humidity control and ventilation } \\
\text { - Etc. }\end{array}$ & $\begin{array}{l}\text { Potential problems in the household facilities. } \\
\text { Recommend energy-saving measures. } \\
\text { - Possible savings in equipment maintenance and renewal. } \\
\text { - Possible savings in high efficiency equipment replacement. } \\
\text { - Possible savings in optimal use of the equipment } \\
\text { - Etc. }\end{array}$ \\
\hline $\begin{array}{l}\text { Potential problems with billing. Advice on revising } \\
\text { energy tariff/plan, or applying for social billing. } \\
\text { - } \quad \text { Possible shift to more economic energy sources. } \\
\text { - } \quad \text { Possible measures in energy supply optimization } \\
\text { - } \quad \text { Ratio energy expenses vs income } \\
\text { - } \quad \text { Meet conditions to apply for aids and subsidies. } \\
\text { - } \quad \text { Time discrimination tariffs. } \\
\text { - Etc. }\end{array}$ & $\begin{array}{l}\text { Potential problems caused by household habits. Advice } \\
\text { on good practice. } \\
\text { - Possible measures in automatic regulation } \\
\text { - Possible measures in training and awareness of energy } \\
\text { consumption drivers. } \\
\text { - Possible measures in seeking advice from social services and } \\
\text { consumer organizations. } \\
\text { - Etc. }\end{array}$ \\
\hline
\end{tabular}

Table 2.- Sections of the training tool

The tool, which was available online, aims to help social workers play a mediating role with energy-impoverished households which are entitled to assistance, as well as detect vulnerable households and present possible mitigation measures. The methodology, which was specifically designed to be used within the framework of the training programme, is based on statistic-descriptive and qualitative analysis. The specific topics under analysis are divided into four different fields. As such, results are measured depending on their potential impact on the households' energy vulnerability.

\section{4.- MAIN RESULTS}

The main aim of this paper was to analyse, from a socio-political perspective, the relative position of social workers in the context of the regional-institutional setting and simultaneously to collect the opinion of the social workers about the energy poverty at regional level. To this goal, the empirical analysis was carried out using a sample of 108 valid observations - $80 \%$ publicly employed social workers and 20\% NGO-employed workers. This proportion of participants is thought to be representative of the distribution of social workers in the region (70\% in urban contexts and $30 \%$ in rural contexts), which is close to the distribution of the population (62\% urban and $38 \%$ rural). $90 \%$ of the participants declared that they had attended households living in conditions of energy poverty. 85\% of participants were women aged 42.6 on average (40\% were under 41 ).

Results indicate that social workers are aware of the problem related to energy poverty and that they consider more active action should be taken, especially those social workers who work in rural areas and for NGOs. 67\% of participants agree that households with no income should have access to free electricity, but they also agree that the amount of electricity supplied in this way must be limited. Although no 
agreement exists concerning this limit, most agree that the electricity bill should depend on income, as illustrated by the answers in the table 3 .

\begin{tabular}{|l|l|l|}
\hline Cod Variable & Questions & Results \\
\hline A.1 & Should utility bills (electricity, gas, etc.) vary according to income? & $70 \%$ agree. Average 6.7 \\
\hline A.2 & $\begin{array}{l}\text { In Aragón, energy poverty poses a grave problem because there } \\
\text { are many households which cannot afford to pay their electricity or } \\
\text { gas bills }\end{array}$ & $90 \%$ agree. Average 8 \\
\hline A.3 & $\begin{array}{l}\text { In households with no income, electricity should be free, up to a } \\
\text { limit }\end{array}$ & $67 \%$ agree. Average 6.4 \\
\hline A.4 & $\begin{array}{l}\text { In Aragón vulnerable households should not have their energy } \\
\text { supply cut off in winter }\end{array}$ & $86 \%$ agree. Average 8.3 \\
\hline A.5 & $\begin{array}{l}\text { Public social services in the Region adequately support energy- } \\
\text { vulnerable households }\end{array}$ & $65 \%$ agree. Average 6.2 \\
\hline A.6 & $\begin{array}{l}\text { Public aid should also be made available to energy-vulnerable } \\
\text { community of owners in the Region }\end{array}$ & $74 \%$ agree. Average 6.9 \\
\hline A.7 & $\begin{array}{l}\text { Public and private agencies are sufficiently coordinated in the } \\
\text { provision of aid aimed at covering outstanding energy bills }\end{array}$ & $43 \%$ agree. Average 5.1 \\
\hline A.8 & $\begin{array}{l}\text { Household energy poverty is being adequately prioritised by } \\
\text { Regional politicians }\end{array}$ & $54 \%$ disagree. Average 4.1 \\
\hline A.9 & $\begin{array}{l}\text { Household energy poverty is being adequately prioritised by } \\
\text { Regional media }\end{array}$ & $55 \%$ disagree. Average 4.2 \\
\hline A.10 & $\begin{array}{l}\text { Regional social movements are the most committed social agent } \\
\text { with regard to energy poverty }\end{array}$ & $50 \%$ agree. Average 5.7 \\
\hline A.11 & $\begin{array}{l}\text { Private agencies and NGOs have been more responsive to the } \\
\text { problem than the public sector in the Region }\end{array}$ & $66 \%$ agree. Average 6.3 \\
\hline NOTE: Level of agreement is calculated as percentage of answers scoring 5 or above. Level of disagreement calculated as percentage of answers below 5. \\
\hline
\end{tabular}

Table 3.- Results of the survey carried out on social workers who deal with energy poverty.

In summary, most of participants (86\%) agree that vulnerable homes should not have their supply cut off in winter. This is the highest-scoring variable (8.3/10), with almost half of the participants ticking 'totally agree'. This indicates a clear consensus among social workers, who openly stand against cutting off the electric supply (Aragon is a relatively cold region, where buildings are often poorly constructed and energy inefficient). This tallies with their close involvement and commitment to current mitigation policies. However, most participants agree that the problem posed by energy poverty cannot be solved by means of urgent ad hoc measures, but rather by fartherreaching decisions, which are beyond their power to implement, but are the responsibility of regional governments, utility companies, national governments and even European institutions.

In order to gain a deeper understanding of the issue, social workers were asked about their subjective perceptions of the visibility of the problem at regional level; $90 \%$ claimed that energy poverty is not regarded as a relevant problem, which stands in sharp contrast to their everyday interactions with families who can barely afford to cover basic needs (housing, food, etc.).

It is also worth underlining that NGO-employed workers think that their response to the problem has been more efficient and flexible than that of publicly employed social workers (66\% agree with an average score of 6.3/10). Similarly, public- and NGOemployed social workers differ concerning whether the public and private agencies are sufficiently coordinated. Only $43 \%$ of all participants think that sufficient coordination exists, with an average score of 5.1/10 (6/10 among NGO-employed social workers). The crucial role played by social workers is unquestionable. Their on-the-ground experience seems adequate argument to continue supporting a system which emphasises attention being paid to rural areas. The perspective of social workers is invaluable concerning the real dimension of energy impoverishment as an indicator of poverty, and 
also concerning the multiple variables that can lead to energy impoverishment and, therefore, the best ways to improve the aid system.

Finally, half of the participants (51\%) disagree that social movements in Aragón have exhibited sufficient awareness of or concern about the issue of energy poverty.

\subsection{Characterisation of households}

The provision of social workers with a specific tool during the training programme helped to get to the root of the problem and increase the efficiency of their assistance. In addition, the tool allowed the characterisation of 55 energy-impoverished households.

34 cases correspond to flats in apartment blocks. The flats have an average of 6 rooms and are $100 \mathrm{~m}^{2}$. Insulation is generally poor. The average temperature is $20^{\circ} \mathrm{C}$ in winter and $24^{\circ} \mathrm{C}$ in summer, which leads to high energy expenses. Only one-third are occupied by tenants, and less than one out of three had been recently refurbished. Heating and water heating systems are described in the figure 4.

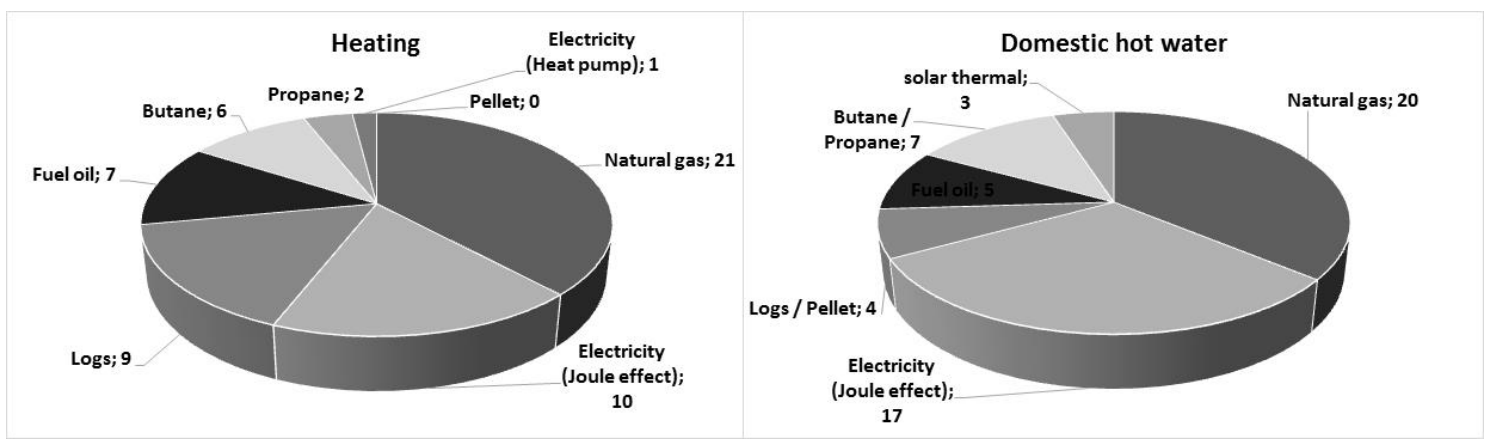

Figure 4.- Distribution of dwellings according to energy source for heating and DHW

We may stress the use of inefficient heating systems, such as electric or gasoil heaters, which made up $30 \%$ of the heating and water-heating systems in use. In addition, $40 \%$ of homes have inefficient lighting systems, and the kitchen appliances are largely electrical.

Half of the households are billed according to a PVPC tariff (a regulated tariff designed for private consumers), while one-third have a free-marked tariff and 9 do not know the terms of their contract. Of those consumers billed according to a PVPC tariff, 7 have been granted a social tariff (social discount for vulnerable consumers). This suggests that more of the households under examination may be entitled to a social tariff, but members of these households do not know how to or are, simply, unaware of the terms of their contracts. The average energy supply in dwellings is $3.6 \mathrm{~kW}$, which is reasonable. The average consumption in winter and summer is illustrated in the following figure. 


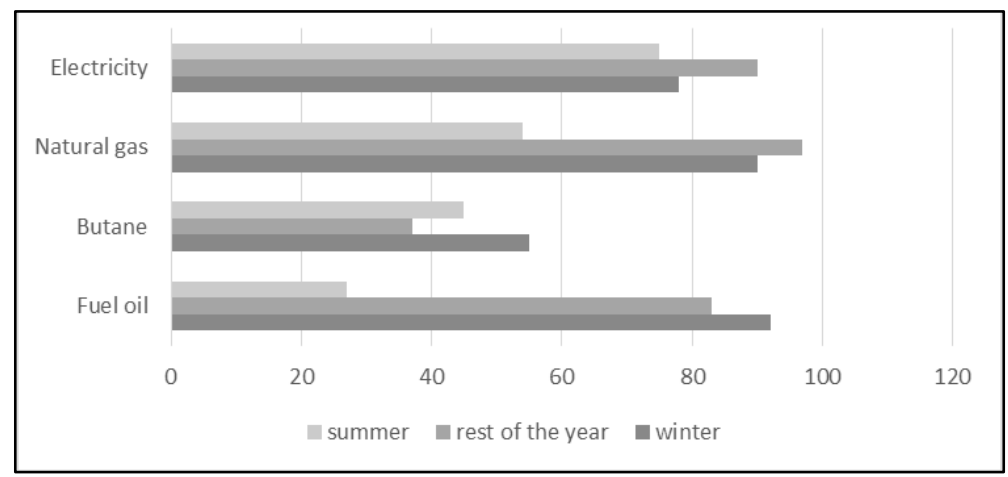

Figure 5.- Energy consumption of the households under examination in winter, summer and throughout the rest of the year (euros)

The total average monthly energy expense is $€ 270$, which seems too high given the income of these households; a significant percentage (46\%) has an income of below $€ 900$ net for the whole household. As a result, $15 \%$ of households claim to have been given a cut-off notice, but state that emergency aid prevented the electricity being cut off.

On the other hand, the data collected thought the tool has contributed to gain a new perspective on the real dimension of the problem posed by energy poverty. Generally, a household is considered to be energy impoverished when the energy-related expenses take over $10 \%$ of the total income (Tirado-Herrero et al., 2014). These statistical data are interesting on a macro level, but they are clearly at odds with the number of households which were in a situation of certified energy poverty and, as such, were granted emergency subsidies. This sort of inconsistency underlines the fact that macrolevel analysis, norms, mitigation measures and the real needs of households must converge.

\subsection{The mediating role of social workers}

Social workers are the central link in the detection and certification of occasional or chronic situations of energy poverty in households in the analysed regional model. They are the mediators who are responsible for verifying the household's (in)ability to meet the energy expenses necessary to maintain reasonable living comfort standards, and activating the social-mitigation mechanisms in place.

The use of the proposed self-diagnosis tool led to the conclusion that the casuistic of energy poverty is varied, and that the emergency aid provided by administrations and ONGs, although effective in solving occasional episodes, cannot solve the underlying problem, which has long-term structural causes. In any case, specific training initiatives are useful for social workers, especially concerning irregularities in consumption and billing; social workers can propose more appropriate tariffs and encourage good consumption practices in order to minimise consumption.

In the case study under analysis, the public network is spread over the whole territory and aims to reach all households and municipalities. This ability to extend mitigation measures to the whole territory has contributed to shifting the burden of social action from private to public agencies.

Social workers, in contrast, emphasise the shortcomings of the system. Although the powers and responsibilities of social workers have increased, no investment has been 
made in order to develop the support network, although some measures have been undertaken which have improved their working conditions. The regional government's support of training initiatives such as that described in this paper is a good example of this.

The initial phase of this research (data-collection), and the evaluation of the results of the energy training programme described, demonstrates that the adequate preparation of professionals needs specific and comprehensive training initiatives: for example, to teach them how to manage technical energy supply/billing issues.

As demonstrated by our analysis, local regulations can hamper the operation of social services and their coordination with the relevant NGOs. The changes in the normative framework in 2014 immediately brought about a transformation in the provenance of emergency funds; before this change, two-thirds of the funds allocated originated from NGOs, whereas now $70 \%$ of the funds are provided by public agencies (see Table 1). The previous regulations limited the assistance that could be provided, not only in relation to the amount of money but also the number of outstanding bills; those limits were removed in $2014^{9}$.

In Spain, in 2016 court rulings ${ }^{10}$ have contributed to the debate on the role that social agents and utility companies must play, emphasising the legal vacuum that exists concerning the scope of social responsibility and access to a basic service. This leaves the most vulnerable sectors of society totally unprotected.

\subsection{Specific measures}

The main measures that can be highlighted to improve the energy poverty intervention at regional level are:

- To create coordination units which facilitate communication and cooperation between agents (public services and ONGs) and contribute to the maximisation of available resources: currently, coordination occurs spontaneously and informally and is largely based on personal relationships between social workers, especially in areas which the public network does not reach.

- To offer social workers specific training and a diagnosis tool with which to make their work more effective. Training and tools will also contribute to increase their knowledge of the underlying causes of energy poverty as a key agent.

- To implement specific policies in order to prevent the gap between exclusion and inclusion from widening even more; the boundary between impoverishment and poverty must be regarded as a red line. On the other hand, public policies have previously been too disperse, which has led to coordination problems and regional inequality.

- To increase the volume of social housing and to implement a specific refurbishment investment program to prevent the energy poverty in households in rural and urban areas.

\footnotetext{
9 Ordenanza Ayuntamiento de Zaragoza, 2014

${ }^{10}$ Recently, a High Court ruling declared that the social tariff regime set out in article 45.4 of Ley 24/2013, de 26 de diciembre, is incompatible with Directive 2009/72/CE, set out by the European Parliament and the Council on 13 July 2009, concerning common rules for the internal market in electricity.
} 
- To define progressive levels of subsidies depending on the level of energy vulnerability or poverty and the situation of the households.

- To define a participative national model to design the main rules for energy poverty, within which all agents, including utility companies and the media, are represented and directed by national, rather than regional, authorities.

\section{6.- CONCLUSIONS AND POLICY IMPLICATIONS}

The case study of a Spanish region has demonstrated that the problem of energy poverty should not be treated locally without the adequate coordination with the national and European regulation, which only postpones achieving a solution for the underlying structural causes.

The model indicates that the initiative is progressively shifting from private to public (local) agents when the Administration increases the activities in this field; the efficiency of the model strongly relies on spontaneous, informal and even improvised relationships between the different agents. However, it is useful for solving occasional emergencies but it does not reach the root of the problem.

While the dichotomy between public and private responsibility goes unresolved, the sustainability of public aid policies, which are largely funded by the social services, will be uncertain. The national legal vacuum (which stems from European directives) has to some extent been corrected at regional level.

Urban and rural households have different problems, and for this reason policies should take into consideration such variables as strength/weakness of social capital, community support strategies, population ageing, the state of conservation of residential buildings and the optimisation of energy resources through the use of traditional systems (for instance, exploitation of nearby forest resources for heating). In any case, although the policies in place seem to be shifting from trying to prevent inequality to the management of poverty and social exclusion, the reasons for the structural discrimination of persons and territories remain unchallenged.

Policies must, therefore, be redefined in order to go beyond the local level, and they must take into consideration structural factors and the restructuring of social aid. The diagnosis of the problem, however, must remain close to the territory, which is where the central role of social workers stands out.

In this context, it is important that regulations take into consideration the mediating role played by social workers at a local level and the present study has contributed to underline their role in energy poverty prevention- an aspect which has been paid little attention to date. In the model under analysis, social workers are responsible for detecting, diagnosing and assisting energy-impoverished households.

A social worker is not an expert on energy consumption and insulation, but rather is the public agent with the best first-hand knowledge of the real problems faced by vulnerable households and of the issues with the buildings in which these families live. As suggested, training can provide the basic knowledge that they need in order to identify the causes of the vulnerability of the households with which they work. It is, 
therefore, necessary to adapt the normative framework to their work and to provide them with better tools to carry out their duties.

The role of social workers as certifying agents is well attuned to the territorial model in place, and that it should be extended to other European regions, since it can be implemented by both public social services (it efficiently covers rural regions) and private (NGO) networks. This is not to say that the model cannot be improved, and this is especially true in relation to the territorial inequalities caused by the diversity of socio-demographic and contextual (urban/rural settings) conditions present in the region.

This study aimed to answer several questions and to increase our knowledge of energy poverty in European households from the point of view of the social workers who deal with the problem first-hand. The limitations of our analysis are obvious, beginning with the small size of the sample and the limitation to one region. This means that there are future challenges: larger samples need to be analysed, and comparative studies should be undertaken, which will include territories in different countries which have different socio-demographic characteristics and assistance models.

\section{ACKNOWLEDGEMENTS}

This research has been made possible by funding from 'Plan de formación dirigido a profesionales de servicios sociales y de ONG de acción social para la optimización energética en hogares en situación de vulnerabilidad en Aragón’ (www.fcirce.es/vulnerabilidadenergetica) by Fundación Endesa, and also by the cooperation of the regional government, specifically the department of citizenship and social rights, Endesa, Fundación CIRCE -Centro de Investigación de Recursos y Consumos Energéticos - and the University of Zaragoza.

We want to express our special gratitude to the professionals who provided the data on which this work is based, to Ramón White and Nieves Belío, from Endesa, José Manuel Casión and de Isabel Vicente, from the Instituto Aragonés de Servicios Sociales (IASS). We also wish to thank Emmanuel Nodem for his assistance in the data-collection processes.

\section{REFERENCES}

Bahaj, A. S., and P. A B James. 2007. 'Urban Energy Generation: The Added Value of Photovoltaics in Social Housing'. Renewable and Sustainable Energy Reviews. doi:10.1016/j.rser.2006.03.007.

Barbeito, A., and R Lo Vuolo. 1992. ‘La Modernización Excluyente. Transformación Económica Y Estado de Bienestar En Argentina’. Buenos Aires (Argentina).

Bartiaux, Françoise, Luísa Schmidt, Ana Horta, and Augusta Correia. 2016. 'Social Diffusion of Energy-Related Practices and Representations: Patterns and Policies in Portugal and Belgium’. Energy Policy 88: 413-21. doi:10.1016/j.enpol.2015.10.046.

Bellver, J. 2015. 'Controversias En Torno a La Pobreza Energética. Diálogo Entre El Centro de Investigación Econimics for Energy (EfE) Y El Observatorio Critico de La Energía’. Papeles de Relaciones Ecosociales Y Cambio Global, 169-80.

Bergasse, E., W. Paczynski, M. Dabrowski, and L. Dewulf. 2013. 'The Relationship between Energy and Socio-Economic Development in the Southern and Eastern Mediterranean'. Edited by MEDPRO Technical Report No. 27/February 2013.

BERR. 2001. 'The UK Fuel Poverty Strategy. Government of United Kingdom'. London: Department for Business Entreprise \& Regulatory. 
Scarpellini, S., Sanz Hernández, M.A., Llera-Sastresa, E., Aranda, J.A., López Rodríguez, M.E., 2017. The mediating role of social workers in the implementation of regional policies targeting energy poverty. Energy Policy 106, 367-375. PRE-PRINT version of: doi:10.1016/j.enpol.2017.03.068

Boardman, B. 1991. Fuel Poverty. Edited by Belhaven Press. London.

Boardman, Brenda. 2004. 'New Directions for Household Energy Efficiency: Evidence from the UK’. Energy Policy 32 (17): 1921-33. doi:10.1016/j.enpol.2004.03.021.

. 2012. 'Fuel Poverty Synthesis: Lessons Learnt, Actions Needed'. Energy Policy 49: 143-48. doi:10.1016/j.enpol.2012.02.035.

Bouzarovski, Stefan. 2011. 'Energy Poverty in the EU: A Review of the Evidence'. Luettavissa: Http://ec. Europa. Eu/regional_policy/..., 1-7.

Bouzarovski, Stefan, Saska Petrova, and Robert Sarlamanov. 2012. 'Energy Poverty Policies in the EU: A Critical Perspective'. Energy Policy 49: 76-82.

doi:10.1016/j.enpol.2012.01.033.

Brunner, Karl Michael, Markus Spitzer, and Anja Christanell. 2012. 'Experiencing Fuel Poverty. Coping Strategies of Low-Income Households in Vienna/Austria'. Energy Policy 49: 53-59. doi:10.1016/j.enpol.2011.11.076.

CESA. 2016. 'Informe Sobre La Situación Económica Y Social de Aragón. Panorama Social.' Zaragoza (Spain).

Chaudhuri, Shubham, and Martin Ravallion. 1994. 'How Well Do Static Indicators Identify the Chronically Poor?’ Journal of Public Economics 53 (3): 367-94. doi:10.1016/00472727(94)90031-0.

Copiello, Sergio. 2016. 'Leveraging Energy Efficiency to Finance Public-Private Social Housing Projects’. Energy Policy 96: 217-30. doi:10.1016/j.enpol.2016.06.003.

Darby, Sarah J. 2012. 'Metering: EU Policy and Implications for Fuel Poor Households'. Energy Policy 49: 98-106. doi:10.1016/j.enpol.2011.11.065.

Dartanto, Teguh. 2013. 'Reducing Fuel Subsidies and the Implication on Fiscal Balance and Poverty in Indonesia: A Simulation Analysis’. Energy Policy 58: 117-34. doi:10.1016/j.enpol.2013.02.040.

Devalière, Isolde. 2010. 'Identification Des Processus de Précarisation Énergétique Des Ménages et Analyse Des Modes D’intervention’.

Dubois, Ute. 2012. 'From Targeting to Implementation: The Role of Identification of Fuel Poor Households’. Energy Policy 49: 107-15. doi:10.1016/j.enpol.2011.11.087.

Eikeland, Per Ove. 2011. 'The Third Internal Energy Market Package: New Power Relations among Member States, EU Institutions and Non-State Actors?' Journal of Common Market Studies 49 (2): 243-63. doi:10.1111/j.1468-5965.2010.02140.x.

European Commission. 2016. 'Communication from the Commission to the European Parliament, the Council, the European Economic and Social Committee, the Committee of the Regions and the European Investment Bank. "Clean Energy for All Europeans" COM(2016) 860 Final'.

European Economic and Social Committee. 2012. 'Opinion of the European Economic and Social Committee on "Energy Poverty in the Context of Liberalisation and the Economic Crisis”.' Official Journal of the European Union C 68: 56-64.

_ 2013. 'Opinion of the European Economic and Social Committee on "For Coordinated European Measures to Prevent and Combat Energy Poverty” (Own-Initiative Opinion)’. Oj C 341/21. 
Scarpellini, S., Sanz Hernández, M.A., Llera-Sastresa, E., Aranda, J.A., López Rodríguez, M.E., 2017. The mediating role of social workers in the implementation of regional policies targeting energy poverty. Energy Policy 106, 367-375. PRE-PRINT version of: doi:10.1016/j.enpol.2017.03.068

Fahmy, Eldin, David Gordon, and Demi Patsios. 2011. 'Predicting Fuel Poverty at a Small-Area Level in England’. Energy Policy 39 (7): 4370-77. doi:10.1016/j.enpol.2011.04.057.

García Escalera, Javier. 2015. 'La Pobreza Energética’. In En González García, E.; García Muñiz, A.; García Sansano, J. E Iglesias Villalobos, L. (Coords.) Mundos Emergentes: Cambios, Conflictos Y Expectativas., edited by ACMS, 615-21. Toledo (Spain).

Grevisse, François, and Marie Brynart. 2011. 'Energy Poverty in Europe : Towards a More Global Understanding’. In , 537-49. ECEEE 2011 Summer Study. Energy Efficiency first: The foundation of Low Carbon Society.

Guertler, Pedro. 2012. 'Can the Green Deal Be Fair Too? Exploring New Possibilities for Alleviating Fuel Poverty’. Energy Policy. doi:10.1016/j.enpol.2011.11.059.

Hamzaoui, M. 2005. 'El Trabajo Social Territorializado: Las Transformación de La Acción Pública En La Intervención Social’. Valencia (Spain).

Healy, John D, and J.Peter Clinch. 2002. 'Fuel Poverty, Thermal Comfort and Occupancy: Results of a National Household-Survey in Ireland'. Applied Energy 73 (3): 329-43. doi:10.1016/S0306-2619(02)00115-0.

Heindl, Peter. 2015. 'Measuring Fuel Poverty in Germany: General Considerations and Application to German Household Data'. FinanzArchiv / Public Finance Analysis 71 (2): 178-215. doi:10.1628/001522115X14285723527593.

Hills, J. 2012. 'Getting the Measure of Fuel Poverty. Final Report of the Fuel Poverty Review.',. London (UK).

Hills, John. 2012. 'Getting the Measure of Fuel Poverty - Final Report of the Fuel Poverty Review: Summary and Recommendations’. doi:ISSN 1465-3001.

Howden-Chapman, Philippa, Helen Viggers, Ralph Chapman, Kimberley O’Sullivan, Lucy Telfar Barnard, and Bob Lloyd. 2012. 'Tackling Cold Housing and Fuel Poverty in New Zealand: A Review of Policies, Research, and Health Impacts'. Energy Policy. doi:10.1016/j.enpol.2011.09.044.

IEA - International Energy Agency. 2011. 'Energy for All. Financing Access for the Poor.'

Jenkins, D. P. 2010. 'The Value of Retrofitting Carbon-Saving Measures into Fuel Poor Social Housing’. Energy Policy 38 (2). Elsevier: 832-39. doi:10.1016/j.enpol.2009.10.030.

Kliksberg, B. 1995. Pobreza, El Drama Cotidiano. Clave Para Una Nueva Gerencia Social Eficiente. Edited by Tesis Norma. Grupo Editorial. Buenos Aires (Argentina).

Laparra, M., and D. Casado. 2013. 'Riesgos de Pobreza, Ingresos Mínimos Y Servicios Sociales.'

Li, Kang, Bob Lloyd, Xiao Jie Liang, and Yi Ming Wei. 2014. 'Energy Poor or Fuel Poor: What Are the Differences?’ Energy Policy. doi:10.1016/j.enpol.2013.11.012.

Liddell, Christine, Chris Morris, S. J P McKenzie, and Gordon Rae. 2012. 'Measuring and Monitoring Fuel Poverty in the UK: National and Regional Perspectives'. Energy Policy 49: 27-32. doi:10.1016/j.enpol.2012.02.029.

Majcen, Da??a, Laure Itard, and Henk Visscher. 2015. 'Statistical Model of the Heating Prediction Gap in Dutch Dwellings: Relative Importance of Building, Household and Behavioural Characteristics'. Energy and Buildings 105: 43-59. doi:10.1016/j.enbuild.2015.07.009. 
Scarpellini, S., Sanz Hernández, M.A., Llera-Sastresa, E., Aranda, J.A., López Rodríguez, M.E., 2017. The mediating role of socia workers in the implementation of regional policies targeting energy poverty. Energy Policy 106, 367-375. PRE-PRINT version of: doi:10.1016/j.enpol.2017.03.068

Moore, Richard. 2012. 'Definitions of Fuel Poverty: Implications for Policy'. Energy Policy 49: 19-26. doi:10.1016/j.enpol.2012.01.057.

Moretón, R. 2015. ‘Acción Contra La Pobreza Energética’. Espacio Público 03-03-2015.

Morrison, Colin, and Niamh Shortt. 2008. 'Fuel Poverty in Scotland: Refining Spatial Resolution in the Scottish Fuel Poverty Indicator Using a GIS-Based Multiple Risk Index'. Health and Place 14 (4): 702-17. doi:10.1016/j.healthplace.2007.11.003.

OECD. 2016. Society at a Glance 2016: OECD Social Indicators. Edited by Co-operation and Development Economic, Organisation for Economic. Paris (France): OECD publishing. doi:http://dx.doi.org/10.1787/9789264261488-en.

Pachauri, Shonali, and Daniel Spreng. 2011. 'Measuring and Monitoring Energy Poverty'. Energy Policy 39 (12): 7497-7504. doi:10.1016/j.enpol.2011.07.008.

Roberts, Simon. 2008. 'Energy, Equity and the Future of the Fuel Poor'. Energy Policy 36 (12): 4471-74. doi:10.1016/j.enpol.2008.09.025.

Rosenow, Jan, Reg Platt, and Brooke Flanagan. 2013. 'Fuel Poverty and Energy Efficiency Obligations - A Critical Assessment of the Supplier Obligation in the UK'. Energy Policy 62: 1194-1203. doi:10.1016/j.enpol.2013.07.103.

Rudge, Janet. 2001. Developing a Methodology to Evaluate the Outcome of Investment in Affordable Warmth: A Report to the Eaga Charitable Trust. London (UK): Eaga Charitable Trust.

. 2012. 'Coal Fires, Fresh Air and the Hardy British: A Historical View of Domestic Energy Efficiency and Thermal Comfort in Britain’. Energy Policy 49: 6-11. doi:10.1016/j.enpol.2011.11.064.

Santamouris, M., K. Kapsis, D. Korres, I. Livada, C. Pavlou, and M. N. Assimakopoulos. 2007. 'On the Relation between the Energy and Social Characteristics of the Residential Sector'. Energy and Buildings 39 (8): 893-905. doi:10.1016/j.enbuild.2006.11.001.

Santamouris, Mathew, John A. Paravantis, Dimitra Founda, Dionysia Kolokotsa, Panagiota Michalakakou, Agis M. Papadopoulos, Nikoletta Kontoulis, et al. 2013. 'Financial Crisis and Energy Consumption: A Household Survey in Greece'. Energy and Buildings 65. Elsevier B.V.: 477-87. doi:10.1016/j.enbuild.2013.06.024.

Santamouris, Mathew, John A Paravantis, Dimitra Founda, Dionysia Kolokotsa, Giouli Michalakakou, and Agis M Papadopoulos. 2013. 'Fuel Poverty and the Financial Crisis: A Households Survey in Greece'. In Proceedings of the 34th AIVC - 3rd TightVent - 2nd Cool Roofs' - 1st Venticool Conference, 1-24. Athens (Greece): Air infiltration and ventilation centre.

Saunders, R. W., R. J K Gross, and J. Wade. 2012. 'Can Premium Tariffs for Micro-Generation and Small Scale Renewable Heat Help the Fuel Poor, and If So, How? Case Studies of Innovative Finance for Community Energy Schemes in the UK'. Energy Policy. doi:10.1016/j.enpol.2011.11.045.

Scarpellini, Sabina, Inés Suárez Perales, and Ana Allué Poc. 2014. 'Alcance de La Pobreza Energética En La Comunidad Autónoma de Aragón’. Zaragoza (Spain).

Scarpellini, Sabina, Pilar Rivera-Torres, Inés Suárez-Perales, and Alfonso Aranda-Usón. 2015. 'Analysis of Energy Poverty Intensity from the Perspective of the Regional Administration: Empirical Evidence from Households in Southern Europe’. Energy Policy 
Scarpellini, S., Sanz Hernández, M.A., Llera-Sastresa, E., Aranda, J.A., López Rodríguez, M.E., 2017. The mediating role of social workers in the implementation of regional policies targeting energy poverty. Energy Policy 106, 367-375. PRE-PRINT version of: doi:10.1016/j.enpol.2017.03.068

86: 729-38. doi:10.1016/j.enpol.2015.08.009.

Sdei, Arianna, Fran??ois Gloriant, Pierre Tittelein, St??phane Lassue, Paul Hanna, Christophe Beslay, Romain Gournet, and Mike McEvoy. 2015. 'Social Housing Retrofit Strategies in England and France: A Parametric and Behavioural Analysis'. Energy Research and Social Science 10: 62-71. doi:10.1016/j.erss.2015.07.001.

Terés-Zubiaga, J., K. Martín, A. Erkoreka, and J. M. Sala. 2013. 'Field Assessment of Thermal Behaviour of Social Housing Apartments in Bilbao, Northern Spain’. Energy and Buildings 67. Elsevier B.V.: 118-35. doi:10.1016/j.enbuild.2013.07.061.

Thomson, Harriet, and Carolyn Snell. 2013. 'Energy Poverty in the EU’. New York (USA).

Tirado-Herrero., S., J.L. López Fernández, and P. Martín García. 2012. Pobreza Energética En España, Potencial de Generación de Empleo Derivado de La Rehabilitación Energética de Viviendas. Edited by ACA Asociación de Ciencias Ambientales. Madrid (Spain).

Tirado Herrero., S., L. Jiménez Meneses, J.L. López Fernández, J. Martín García, and E. Perero Van Hove. 2014. Pobreza Energética En España. Análisis de Tendencias. Edited by ACA Asociación de Ciencias Ambientales. Madrid (Spain).

Tirado Herrero, S., L. Jiménez Meneses, JL. López Fernández, E. Perrero Van Hove, VM. Irigoyen Hidalgo, and P. Savary. 2016. Pobreza, Vulnerabilidad Y Desigualdad Energética. ACCA - Asociación de Ciencias ambientales.

Tirado Herrero, Sergio, and Stefan Bouzarovski. 2015. 'Energy Transitions and Regional Inequalities in Energy Poverty Trends : Exploring the EU Energy Divide'. In , 1-45. doi:10.2139/ssrn.2537067.

Tirado Herrero, Sergio, and Diana Ürge-Vorsatz. 2012. 'Trapped in the Heat: A PostCommunist Type of Fuel Poverty’. Energy Policy. doi:10.1016/j.enpol.2011.08.067.

Waddams Price, Catherine, Karl Brazier, and Wenjia Wang. 2012. 'Objective and Subjective Measures of Fuel Poverty’. Energy Policy. doi:10.1016/j.enpol.2011.11.095.

Walker, Gordon, and Rosie Day. 2012. 'Fuel Poverty as Injustice: Integrating Distribution, Recognition and Procedure in the Struggle for Affordable Warmth'. Energy Policy. doi:10.1016/j.enpol.2012.01.044.

Walker, Ryan, Christine Liddell, Paul McKenzie, and Chris Morris. 2013. 'Evaluating Fuel Poverty Policy in Northern Ireland Using a Geographic Approach'. Energy Policy. doi:10.1016/j.enpol.2013.08.047.

Yu, Zhun, Benjamin C M Fung, Fariborz Haghighat, Hiroshi Yoshino, and Edward Morofsky. 2011. 'A Systematic Procedure to Study the Influence of Occupant Behavior on Building Energy Consumption'. Energy and Buildings 43 (6): 1409-17. doi:10.1016/j.enbuild.2011.02.002. 